\title{
Natural Resource Abundance (Black Gold) and Investment in Human Capital in the Context of Saudi Arabia
}

\author{
Najla Almutairi \\ Management and Humanities Science Department, King Saud University, Saudi Arabia
}

\begin{abstract}
A number of studies have suggested that an abundance of natural resource gives rise to what is known as 'Dutch disease', and also distorts the quality of institutions. In contrast, this paper examines whether plenty of natural resource crowds out human capital in the context of Saudi Arabia using the VECM model. The study investigates this relationship at the country level rather than through panel or cross-section data as is the case in most other studies. The results show that natural resources have a positive effect on human capital. The presence of natural resources and their rents enable investment in education. This, in turn, facilitates the building of human capital. The link between education and human capital accumulation is complex and more investment in education does not automatically lead to more human capital accumulation. To conclude, it is incorrect to assume the harmful effect of resources on human capital in all resource-rich economies, without a detailed examination of country specific historical data.
\end{abstract}

Keywords: natural resource curse, transmission channels of curse, human capital, growth, education, Dutch disease, Saudi economy, unit root and cointegration tests, VAR model.

DOI: $10.7176 / \mathrm{JESD} / 10-22-10$

Publication date: November $30^{\text {th }} 2019$

\section{Introduction}

Most recent literature argues that natural resources are a curse rather than a boon, as data from the 19th Century indicate that resource rich economies experienced lower growth rates relative to their resource-poor counterparts. Natural resources are described as 'a paradoxical phenomenon' because, as a factor of production, they should help to increase output. Reduced economic growth in the presence of abundant natural resources is generally explained through five theoretical transmission channels: Dutch disease, rent seeking, the neglect of investment in education or human capital, the lowering of investment and saving, and the poor quality of institutions. For more details on these channels see (Corden \& Neary, 1982; Krugman, 1987; Gelb, 1988; Matsuyama, 1992; Lane \& Tornell, 1996; Collier \& Loeffler, 1998; Baland \& Francois, 2000; Birdsall et al., 2001; Gylfason, 2001; Torvik, 2002; Hodler, 2006 and Cabrales \& Hauk, 2011). One such channel is the tendency to neglect investment in human capital. This is the focus of the paper. The aim of this study is to find out whether an abundance of natural resources distorts economic growth by crowding out investment in human capital.

Growth models find that human capital is a key determinant of economic growth because highly educated workers play an essential role in developing new technology and in the diffusion of existing technologies (Nelson \& Phelps, 1966; Romer, 1990; Becker et al., 1994; and Lucas, 1988). A model developed by Galor and Weil (2000) suggests that having a high-density population helps significantly in raising the level of technology by facilitating the diffusion of knowledge. Consequently, the returns on investment in education increase, and in turn more technological changes take place.

However, recent literature suggests that the role of human capital in fostering economic growth may be hampered by natural resource abundance. Theories about natural resources and their impact on human capital are still scarce. Shao and Yang (2014) argue that resource-based industries have less demand for highly skilled labour as they depend on a lower level of technology compared to manufacturing. Thus, the returns to investment in education and human capital will decrease, and growth rates will diminish as a result. In addition, the volatility of resource goods' prices increases the uncertainty of the return to investment.

Cabrales and Hauk (2011) make a different argument in which institutional quality can determine the nature of the relationship between natural resources and human capital. Here, the presence of high-quality political institutions can ensure a positive relationship between natural resources and human capital, and low institutional quality can give rise to negative effects.

A further argument is that governments in resource-based economies may neglect investment in human capital as a result of their wealth. Birdsall et al. (2001) point out that many governments with limited finances can only make small investments in human capital, despite extolling the benefits of education. Hence, the authors argue, that if low investment in education results from a lack of money, more investment in education should be induced by an abundance of natural resources. However, the statistics tell a different story. Resource-rich countries on average spend less on education in comparison to others. Gylfason (2001) notes that:

$[\mathrm{N}]$ ations that are confident that their natural resources are their most important asset may inadvertently - and perhaps even deliberately! - neglect the development of their human resources, by devoting inadequate attention 
and expenditure to education (Gylfason, 2001, p.850).

Our study builds on the limited amount of previous literature in three main ways. First, it examines whether there is a positive relationship between natural resources and human capital in oil-rich Saudi Arabia. This is a developing country endowed with huge quantities of natural resources, particularly oil. It is classified among the largest oil-exporting nations in the world, and oil accounts for more than 50\% of its GDP. Saudi Arabia is therefore an appropriate location for an empirical examination of whether the natural resources curse operates via human capital. Second, in contrast to the literature on this subject, we employ the vector autoregressive (VAR) model, which is useful for prediction, simple in estimation and popular in analysing multivariate time series. Third, this study tests the relationship between natural resources and human capital, where previous studies extend the growth regression to include the interaction between natural resources and human capital or use the correlation between these two variables. This may not produce reliable results as this approach only considers the effect of such interactions on growth and is not permitted to capture the direct effect of natural resources on human capital. In our study we examine the direct relationship between natural resources and human capital by estimating a human capital equation, benefiting from the dynamic VAR framework.

The results of VECM estimates suggest that natural resources relate positively and significantly with human capital, suggesting that the natural resources curse via human capital is not pronounced in Saudi Arabia.

The rest of the paper is structured as follows: Section (2) reviews the empirical literature on the effect of natural resources on the accumulation of human capital. The methodology and data employed in the present paper are provided in Section (3). The empirical findings are presented and discussed in the section (4) while a final section (5) presents the conclusion.

\section{Literature Review}

Just as theoretical models of the effects of natural resource abundance on human capital accumulation are scarce, so also are empirical studies of the issue. The findings of such studies are mixed. One group of studies finds a positive relationship between natural resources and human capital (Davis, 1995; Stijns, 2006; Emery et al., 2012). Another group finds that natural resource abundance relates negatively with human capital and confirms the presence of the resource curse (Birdsall et al., 2001; Gylfason, 2001; Kumar, 2014). Finally, a third group finds neutral results, in that natural resources can be a curse or benefit depending on certain conditions such as the quality of institutions and the type or the density of natural resources (Behbudi et al., 2010; Blanco \& Grier, 2012; Cabrales \& Hauk, 2011; Toews \& Lipman, 2013).

There are several possible explanations for these differences in the results. Three main explanations are investigated in the existing literature. The first of these relate to the measurement of both natural resources and human capital where the use of different or invalid measures can lead to biased results. Gylfason (2001) who found negative relationship between natural resources and human capital using three measures of human capital: public expenditure on education relative to national income; girls' expected years of schooling; and gross secondary school enrolment. His measure of natural resource is the share of natural capital in national wealth.

Stijns (2006) criticised the measurement of natural resources used by Gylfason (2001) and Birdsall et al. (2001) in arriving at the conclusion that there was an inverse relationship between natural resources and human capital. He disagreed with Gylfason's measurement (the share of natural capital in national wealth) because it included 'green capital' such as timber, non-timber, cropland and pastureland in natural capital along with 'subsoil wealth'. Stjns argued that separate indicators of green capital and subsoil-wealth are required as each has different effects on human capital and that the term of natural capital should be used only to refer to subsoil wealth such as fuels and minerals. Similarly, the author argued against the proxy (arable land per capita) used in Birdsall et al. (2001) since this indicator cannot be a proper measure of natural resource wealth in countries such as Saudi Arabia which have a small share of arable land. Stjns suggests that the researcher should adopt measures that suit the objectives of the research.

Another issue that has arisen in the empirical literature is that the effect of natural resource on human capital accumulation is simply a reflection of the high or low price of oil. Davis (1995) used historical data to make comparisons between (22) mineral-based economies and (57) non-mineral based economies. The comparison involved eight indicators of human development in two different periods: the period that before the boom in oil price (1970) and the period after the boom had stabilised (1991). Inspection of the data for the periods of both high and low prices confirmed that the economic and development performance of countries that have minerals exceeds, or is similar to, the performance of those without minerals in the long term in both time periods.

The results obtained by Emery et al., (2012) provide an interesting twist in that they suggest that where citizens have to fund their own studies, an oil boom provides the opportunity to build up an amount of money which can be invested in the completion of education at a later stage. In other words, such resources only changed the time of enrolment in school. Although the authors do not regard this as a negative impact, it might be countered that a delay in the timing of schooling is likely to have an impact on the long-term building human capital. This is a point which could be considered in the future research. In contrast, Kumar (2014) explored the effects of an oil 
boom on human capital and wages in the period from 1970 to 2010 in the U.S. The main focus of Kumar's attention was Texas as an oil-intensive state. He concludes that an oil boom causes real wages to dramatically increase in oil regions compared to non-oil regions. In addition, the oil boom exerts a negative effect on human capital in two paths: (1) the increase in opportunity cost of additional schooling and (2) the decrease in returns that are gained by completing higher education (college).

Some literature pays more attention to the importance of distinguishing between different types of natural resources, or even variation in their quantities across countries, in testing for their effects on human capital accumulation. Behbudi et al. (2010) used panel data analysis for the period 1970-2004 to test whether natural resources have a negative impact on human capital. They divided countries into two groups based on the share of petroleum exports in the total exports: the first group includes countries that have a share of petroleum in exports of $50 \%$ or above, while the second group includes countries that have a small share of petroleum exports in total exports. The results indicated that the link between natural resources and human capital is negative in the first group compared to the second group. The result suggests that a major share of petroleum exports plays a significant role in decreasing the level of human capital.

In 17 Latin American countries in the period from 1975 to 2004, Blanco and Grier (2012) divided natural resources into three categories: mineral, petroleum and agricultural. Their findings confirmed that different types of natural resources are likely to impact differently on capital accumulation. In countries which depend primarily on mineral exports there was no significant relationship between resource exports and the two forms of capital. On the other hand, they found that petroleum exports encourage physical capital and inhibit human capital, while agricultural exports exert negative effects on both physical and human capital.

To conclude, the issue of the relationship between natural resources, human capital and thus economic growth has remained a source of significant contention in both theoretical and empirical literature. The issues are complex and have several dimensions. However, the contribution of Stijns (2006), Behbudi et al. (2010) and Blanco and Grier (2012) seem to indicate that country-specific factors are likely to be important. This study seeks to contribute to the literature by focusing exclusively on Saudi Arabia. Saudi Arabia is an oil-based economy, but it differs from other such economies in the extent of its dependence on this resource. In addition, this study examines the direct relationship between natural resources and human capital by estimating human capital regression with consideration for other variables which may affect human capital and so be included in the regression. More details on the methodology and data are provided in the following section.

\section{Methodology and Data}

In order to investigate the effect of natural resource abundance on human capital in Saudi Arabia, this study covers the period from 1972 to 2014. This study tries as far as possible to use earlier time periods to capture oil price shocks and changes in human capital over the medium to long term. Unlike other studies exploring the relationship between natural resources and human capital, this study uses a vector autoregressive (VAR) model. This is a popular technique used in the analysis of time series data, and it extends the univariate autoregressive model to multivariate time series. In general, the VAR model is used as a beneficial tool in the prediction of multiple time series variables. Lütkepohl, and Krätzig (2004, p.86) state that:

Vector Autoregressive (VAR) processes are a suitable model class for describing the data generation process (DGP) of a small or moderate set of time series variables. In these models all variables are often treated as being a priori endogenous, and allowance is made for rich dynamics.

The VAR model has several advantages. For example, it provides flexibility and simplicity as there is no need to distinguish between exogenous and endogenous variables ${ }^{1}$, unlike simultaneous equation models. The VAR model can also capture feedback effects (Enders, 2004). In addition, Asteriou and Hall (2011, p. 321) note that, 'forecasts obtained from VAR models are in most cases better than those obtained from the far more complex simultaneous equation models.' The econometrics technique in this study begins by formulating the vector autoregressive (VAR) model for a set of $K$ variables $y_{t}=\left(y_{1 t}, \ldots, y_{k t}\right)^{\prime}$ :

$\mathrm{y}_{\mathrm{t}}=\mathrm{A}_{1} \mathrm{y}_{\mathrm{t}-1}+\cdots+\mathrm{A}_{\mathrm{p}} \mathrm{y}_{\mathrm{t}-\mathrm{p}}+\mathrm{u}_{\mathrm{t}}$

As $A_{i}{ }^{\prime}$ s are $(K \times K)$ coefficient matrices and $u_{t}=\left(u_{1 t}, \ldots, u_{k t}\right)^{\prime}$ is an unobservable error term which is assumed to be a zero-mean independent white noise process with time-invariant. The positive definite covariance matrix is $\mathrm{E}\left(\mathrm{u}_{\mathrm{t}} \mathrm{u}_{\mathrm{t}}^{\prime}\right)=\sum_{\mathrm{u}}{ }^{2} \mathrm{p}$ indicates the number of lags ${ }^{3}$. All variables which enter the VAR model are treated as endogenous. The VAR model with $\mathrm{K}$ variables consists of $\mathrm{K}$ equations. In each equation of a VAR, the variable on the left-hand side is the value of one variable at time $t$, and the variables on the right-hand side are the lagged values of all the variables which appear on the left-hand side of any of the VAR equations. In addition, each equation in the system has the same set of regressors. The model is estimated simply by the ordinary least squares

\footnotetext{
${ }^{1}$ For more information see (Sims, 1980).

${ }^{2}$ See Lütkepohl and Krätzig (2004)

${ }^{3} \mathrm{Lag}$ length is determined by the information-based criteria.
} 
(OLS) and each equation is estimated separately.

As a first step it is important to test the integration of variables, and whether they are stationary $\mathrm{I}(0)$. The process will be estimated using the vector autoregressive (VAR) method. However, if some or all of the variables have a unit root, the test of cointegration must be conducted and thus the data generating process is modelled as the Vector Error Correction (VECM) model. There are a number of studies which have focused on the order of integration in time-series and various statistical tests have been proposed to verify the stationarity of a series. See for example (Dickey \& Fuller, 1979; Dickey et al., 1984; Phillips \& Perron, 1988; Elliott et al., 1996 and Ng \& Perron 2001). This study will consider the unit root test of Dickey and Fuller (1979).

After testing the unit root, if some or all the variables are non-stationary, a cointegration test must be performed. The idea is that as most macroeconomic variables are non-stationary, there is a need for a cointegration test. According to the definition introduced by Engle and Granger (1987), cointegration is a stationary linear combination of non-stationary variables. This study follows Johansen (1995) who developed a test for cointegrating rank.

Once the cointegration rank is specified, the VECM model can then be modelled as follows:

$\Delta \mathrm{y}_{\mathrm{t}}=\Pi_{\mathrm{t}-1}+\Gamma_{1} \Delta \mathrm{y}_{\mathrm{t}-1}+\cdots+\Gamma_{\mathrm{p}-1} \Delta \mathrm{y}_{\mathrm{t}-\mathrm{p}+1}+\mathrm{u}_{\mathrm{t}}$

Where $\Gamma_{\mathrm{p}-1}$ represents the short-run part, while $\Pi_{\mathrm{t}-1}$ indicates the long-term part. When a VECM is estimated, it is important to check whether the model adequately mimics DGP. There are several tests which can be used to diagnose the adequacy of the model, including the autocorrelation and heteroskedasticity tests.

As this study aims to examine the effect of the abundance in natural resources on human capital in the Saudi Arabian economy, it is proposed that the measure which best fulfils this objective is the rents derived from the oil exports. Oil rents can clearly capture the abundance in natural resources in the case of Saudi Arabia where such rents constitute more than half of GDP. While oil reserves are another possible proxy commonly used in the literature, data on reserves is not available for all the years in the relevant time period. To measure human capital, we use a common indicator of educational attainment indicators in the literature as these indicators are closely correlated with investment in education and are widely regarded as the most important element in human capital formation.

This indicator is gross enrolment rate for tertiary level education ${ }^{1}$. It would have been preferable to use other schooling levels (primary and secondary) as a sensitivity check for the results, but unfortunately the lack of annual data restricts the study to tertiary education. The World Bank (2002, p.21) notes, 'Investments in tertiary education generate major external benefits that are crucial for knowledge-driven economic and social development.' This indicator is appropriate in the case of Saudi Arabia as education levels in the country are relatively high; enrolment rates in tertiary education stood at $68.9 \%$ in 2017 and reached $116.6 \%$ for secondary education in 2014 (World Bank, 2017). In addition, scholarships in Saudi Arabia are restricted to tertiary education, and in recent years the number of scholarships has increased significantly, particularly due to the great attention and investment made by the Saudi government.

To estimate the human capital equation, we control for the other variables which may also affect human capital including GDP growth, government expenditure and political institutions. Birdsall et al. (2001) argue that human capital investments play an important role in enhancing growth, as predicted by endogenous growth theory. In turn, having high growth rates gives rise to high human capital rates which continues the virtuous circle of growth. In their theoretical model, Shao and Yang (2014) propose that by considering education a public good, spending on education by a government, in terms of offering the necessary material and financial resources to provide households with more educational opportunities, can increase the returns on education and thus stimulate human capital accumulation and growth. Empirically, Gupta et al. (2002) found that more expenditure on education and healthcare gives rise to higher school attainment levels in developing and transition countries.

With regard to political institutions and their link to human capital, Gallego (2010) argues that political institutions affect educational attainment which may explain why schooling levels differ across countries. By testing this hypothesis empirically, they found that political institutions measured via democracy relate positively with primary education in 50 former colonies. He also states that there are several theories which focus on human capital and its relationship to government behaviour and institutions, making two main arguments. The first argument stresses the importance of public policies in overcoming failures such as market credit constraints in financing education. The second argument states that political institutions determine the implementation of educational policies. As mentioned throughout the paper, political institutions can determine the nature of the relationship between natural resources and human capital (Cabrales and Hauk, 2011). The authors' theoretical model suggests that there is a clear relationship linking such institutions with human capital. In our study we use civil liberties to measure political institutions. The definitions of variables employed in this study and their sources are illustrated in Table 1 and all variables are expressed in the logarithmic form, excepting GDP growth.

\footnotetext{
${ }^{1}$ The lack of available data on Saudi Arabia restricts us to employing other alternative indicators of educational attainment commonly used in the literature, such as average years of education.
} 
Table 1. The Definition of Data and its Source

\begin{tabular}{|l|l|l|}
\hline \multicolumn{1}{|c|}{ Variable } & \multicolumn{1}{c|}{ Definition } & \multicolumn{1}{c|}{ Source } \\
\hline LHC & Gross enrolment ratio, tertiary level, both sexes (\%) & World Bank (WDI, 2017) \\
\hline LOILRENT & Oil rents as a share of GDP (\%) & World Bank (WDI, 2017) \\
\hline LGOVEXP & Government expenditure as a share of GDP (\%) & World Bank (WDI, 2017) \\
\hline GROWTH & GDP growth (\%) & World Bank (WDI, 2017) \\
\hline LCL & Civil liberties & Freedom House (2016) \\
\hline
\end{tabular}

\section{The Main Results and Discussion}

As mentioned above, the unit root test is the first step in the econometrics method of study. For this reason, the unit root test was performed. To do this, lag order and deterministic terms must be specified beforehand. To determine lag order, we follow information-based criteria, in particular Hannan-Quinn criterion (HQC). This criterion in particular was used as it is proven by Hall (1994) that $\mathrm{P}\left(\mathrm{P}^{\wedge}=\mathrm{P}_{0}\right)=1$ is satisfied by Schwarz and Hannan and Quinn. In addition, Johansen et al. (2000) suggest that where information criteria show differences in the value of optimal lag length, HQIC is preferable and commonly used in practice. According to these criteria, the true lag order is selected by the order that minimises the criterion. The guidance of Dolado et al. $(1990)^{1}$, was followed to determine the true deterministic terms which must be included in the model.

Using the Hannan-Quinn Criterion (HQIC) with the maximum lag order (3), the true lag order of variables was determined, as shown in Table 2. The results of the unit root test revealed that only (GROWTH) is stationary in level while the rest of variables has a unit root, and so we cannot reject the null hypothesis of unit root. However, they became stationary in the first difference.

Table 2. Unit Root Test (ADF)

\begin{tabular}{|c|c|c|c|c|c|c|c|}
\hline \multirow[t]{2}{*}{ Variable } & \multirow{2}{*}{$\begin{array}{c}\text { Lag } \\
\text { (HQIC) }\end{array}$} & \multirow[t]{2}{*}{ Deterministic Terms } & \multirow{2}{*}{$\begin{array}{c}\mathrm{t}- \\
\text { statistics }\end{array}$} & \multicolumn{3}{|c|}{ Critical Value* } & \multirow[t]{3}{*}{ P-Value } \\
\hline & & & & $1 \%$ & $5 \%$ & $10 \%$ & \\
\hline \multicolumn{7}{|c|}{ Level } & \\
\hline LHC & 1 & $\mathrm{c}$ & -1.76 & -3.59 & -2.93 & -2.60 & 0.39 \\
\hline LOILRENT & 0 & $\mathrm{c}$ & -2.61 & -3.59 & -2.93 & -2.60 & 0.09 \\
\hline GROWTH & 1 & non & -3.97 & -2.62 & -1.94 & -1.61 & 0.00 \\
\hline LGOVEXP & 0 & $\mathrm{c}$ & -2.56 & -3.59 & -2.93 & -2.60 & 0.10 \\
\hline LCL & 0 & $\mathrm{c}$ & -2.36 & -3.59 & -2.93 & -2.60 & 0.16 \\
\hline \multicolumn{8}{|c|}{ First Difference } \\
\hline$\Delta \mathrm{LHC}$ & 0 & $\mathrm{c}$ & -4.07 & -3.59 & -2.93 & -2.60 & 0.00 \\
\hline$\Delta$ LOILRENT & 1 & non & -6.49 & -2.62 & -1.94 & -1.61 & 0.00 \\
\hline$\triangle \mathrm{LGOVEXP}$ & 0 & non & -7.68 & -2.62 & -1.94 & -1.61 & 0.00 \\
\hline$\Delta \mathrm{LCL}$ & 0 & non & -6.32 & -2.62 & -1.94 & -1.61 & 0.00 \\
\hline
\end{tabular}

$\mathrm{C}$ and non denote constant and no constant \& linear trend respectively. It was conducted using the software EViews.

As most variables are not stationary in a level and thus are integrated I(1), the cointegration test was performed. Similarly, to the unit root test, both lag order and deterministic components must be established prior to conducting the cointegration test. Lag order was selected using the Hannan-Quinn Criterion (HQIC) with maximum lag (3). The deterministic components were specified according to the Pantula principle ${ }^{2}$ as reported in Table 3.

Table 3. Cointegration rank test

\begin{tabular}{|c|c|c|c|}
\hline Null Hypothesis & LR-test & P-Value & Critical Value 5\%* $^{*}$ \\
\hline \multicolumn{4}{|c|}{ Using lag (1), constant and trend in the cointegration relation } \\
\hline $\mathrm{r}=0$ & 106.71 & 0.00 & 88.80 \\
$\mathrm{r}=1$ & 59.31 & 0.11 & 63.88 \\
\hline
\end{tabular}

It was conducted using the software EViews.

Table 3 indicates that there is only one cointegrating vector at $5 \%$. Once the cointegrating relation rank was specified, the VECM models were estimated using Johansen. The cointegration relation produced by LM estimation with the normalization of $\mathrm{LHC}_{t}$, to 1 is shown in the Table 4.

After the estimation of the VECM model, the adequacy of the model was checked by considering diagnostic tests including autocorrelation and hetreroskedasticity. The study runs both the Breusch-Godfrey LM and portmanteau tests to inspect the presence of autocorrelation in residuals. Indeed, choosing lag length is an

\footnotetext{
${ }^{1}$ For more information on this guidance see Enders (2004)

${ }^{2}$ The Pantula principle is to move from the most to the least restrictive model, stopping when the null hypothesis of no cointegration cannot be rejected, see (Johansen, 1992).

${ }^{3}$ There are five cases which can be considered for cointegration testing, see ((Juselius, 2006).
} 
important aspect in both tests, and Lütkepohl and Krätzig, (2004) note that while the LM test requires a small lag order, the portmanteau tests needs a larger lag length. Lag 2 and 4 were used in the LM test, whereas lag 10 and 12 were selected for the portmanteau test. Table 5 shows that the LM test with two different lags cannot reject the null hypothesis of no autocorrelation.

Table 4. Cointegration Vector (Normalized)

\begin{tabular}{|c|c|}
\hline \multicolumn{2}{|r|}{ With lag (0), constant and trend in the cointegration relation } \\
\hline$L H C_{t}$ & 1 \\
\hline LOILRENT $_{t}$ & $\begin{array}{c}-0.49 \\
(0.11) \\
{[-4.58]}\end{array}$ \\
\hline GROWTH & $\begin{array}{c}0.02 \\
(0.00) \\
{[8.29]}\end{array}$ \\
\hline LGOVEXP & $\begin{array}{c}-0.54 \\
(0.11) \\
{[-4.89]}\end{array}$ \\
\hline$L C L_{t}$ & $\begin{array}{c}-0.69 \\
(0.38) \\
{[-1.79]}\end{array}$ \\
\hline $\mathbf{C}$ & 3.64 \\
\hline $\mathbf{t}$ & 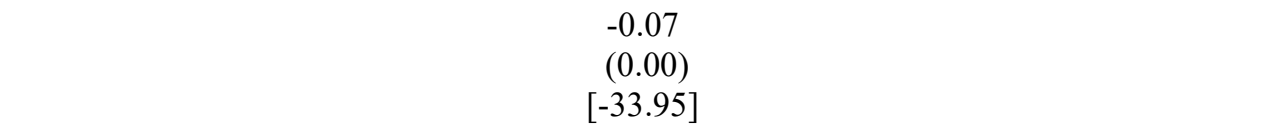 \\
\hline $\begin{array}{l}\text { OR } \\
\text { alternatively: }\end{array}$ & $\begin{aligned} \text { LHC }_{t}=0.49 L O I L R E N T_{t}-0.02 G R O W T H_{t} & +0.54 L G O V E X P_{t}+0.69 L C L_{t}-3.64 \\
& +0.07_{t}\end{aligned}$ \\
\hline
\end{tabular}

Standard deviation and t-statistics given in ( ) and [ ] respectively. Notice: lag order in VECM model is reduced by one lag to the VAR model. It was conducted using the software EViews.

In addition, the portmanteau and adjusted portmanteau tests confirm that the residuals are not correlated with lag 10 and 12. In addition to the autocorrelation test, a hetreroskedasticity test was run and the results support that there is no hetreroskedasticity in residuals with Chi-square (43.19) and p-value (0.06). To conclude, the model passed the adequacy test.

Table 5. Residual autocorrelation test of model

\begin{tabular}{|c|c|c|c|c|c|c|}
\hline Test & $\mathbf{L M}(\mathbf{2})$ & $\mathbf{L M}(\mathbf{4})$ & $\mathbf{Q 1 0}$ & $\mathbf{Q} \mathbf{1 0}^{\mathbf{1 0}}$ & $\mathbf{Q 1 2}$ & $\mathbf{Q}^{*} \mathbf{1 2}$ \\
\hline t-statistics & 60.03 & 95.29 & 229.25 & 263.67 & 264.63 & 312.36 \\
P-value & 0.16 & 0.61 & 0.97 & 0.61 & 0.99 & 0.62 \\
$\begin{array}{c}\text { Degree of } \\
\text { freedom }\end{array}$ & 50 & 100 & 271 & 271 & 321 & 321 \\
\hline
\end{tabular}
EViews.

Q Indicates to portmanteau test, and $\mathrm{Q}^{*}$ to adjusted portmanteau test. It was conducted using the software

The cointegrating relationship shown in the Table 4 indicates that an abundance of natural resources has a positive and significant impact on human capital, suggesting that the natural resources curse is not evident for human capital in the case of Saudi Arabia. These results contrast starkly with Gylfason's results who produced evidence of a negative effect of natural resource abundance on human capital investment. The results also suggest that, contrary to the assertions of Gylfason (2001) and Birdsall et al. (2001) resource-based economies do not necessarily underestimate the importance of investment in education.

However, Gylfason (2001) uses a general measure of natural resources (share of natural capital in national wealth), while this study focuses on oil. This may confirm Stijns (2006) perspective that it is important to distinguish between the different types of natural resources when determining the nature of the relationship between natural resources and human capital. Stijns (2006) found a positive relationship between natural resources and human capital in the case of arable land, but this relationship is negative for minerals. Interestingly, although both minerals and oil belong to point-source resources; they have different effects on human capital.

Our results differ from those of Blanco and Grier (2012) who found a negative relationship between petroleum 
and human capital in 17 Latin American countries. This is may be because they use the share of petroleum in total exports which is widely accepted as a measure of natural resource dependence rather than natural resource abundance.

\section{Conclusion}

This paper sought to present further evidence on whether an abundance of natural resources is a boon or a curse in relation to human capital, taking Saudi Arabia as an example. To estimate this relationship, the study used the VECM model, covering the period from 1972 to 2014. The estimates of VECM model present new evidence of the positive relationship between natural resources as measured by the share of oil rents in GDP and human capital measured by gross enrolment rates for tertiary level education. According to this result, the natural resources curse may not operate via human capital.

However, it is important to bear in mind that the quality of education has not been accounted for and more education does not necessarily mean more human capital accumulation. To accurately verify our conclusion about the positive relationship between natural resources and human capital, we would need to use measures of human capital which account for education quality. Hanushek and Wößmann (2007) have emphasised that it is the quality of education not expenditure or years of education which matters for economic growth. In the case of Saudi Arabia, the results of international student tests indicate that there are some problems with the quality of provision (McKinsey \& Co., 2015). It seems plausible that using such a measure of human capital may yield different results. There are still some attempts in the literature to construct measures of human capital which reflect the quality of education. It is important to consider this in future work as inappropriate measures of human capital may lead to unreliable results which in turn influence policy.

In terms of theoretical implications, this study focuses on a single natural resource (oil) and has produced results which differ from studies which consider broader mineral groups. This suggests that the type of natural resource is key for understanding the effect of natural resource abundance on human capital. Theory has suggested that during oil boom returns to education in oil abundant countries falls as resource-based industries have less demand for education. Hence, the demand for education decreases per household. However, this neglects the fact that many major oil producing countries, including Saudi Arabia, heavily incentivise remaining in education. There is free public education at all levels, and provision of internal and external scholarships. These programmes may encourage individuals to remain in education rather than moving into employment. The effects of these types of programmes have often been neglected by theorists and may explain why negative relationships are often proposed.

\section{References}

Asteriou, D. and Hall, S. (eds.) (2011) Applied Econometrics. 2nd edn. London: Palgrave Macmillan.

Baland, J. and Francois, P. (2000) 'Rent-seeking and resource booms', Journal of Development Economics, 61(2), pp. 527-542.

Becker, G.S., Murphy, K.M. and Tamura, R. (1994) 'Human capital, fertility, and economic growth' in Becker, G.S. (eds.) Human Capital: A Theoretical and Empirical Analysis with Special Reference to Education. USA: National Bureau of Economic Research, Inc, pp. 323-350.

Behbudi, D., Mamipour, S. and Karami, A. (2010) 'Natural resource abundance, human capital and economic growth in the petroleum exporting countries', Journal of Economic Development, 35(3), pp. 81-102.

Birdsall, N., Pinckney, T. and Sabot, R. (2001), Natural resources, human capital and growth. Working Papers. Washington: Carnegie Endowment for International Peace.

Blanco, L. and Grier, R. (2012) 'Natural resource dependence and the accumulation of physical and human capital in Latin America', Resources Policy, 37(3), pp. 281-295.

Cabrales, A. and Hauk, E. (2011) 'The quality of political institutions and the curse of natural resources', The Economic Journal, 121(551), pp. 58-88.

Collier, P. and Hoeffler, A. (1998) 'On economic causes of civil war', Oxford economic papers, 50(4), pp. 563573.

Corden, W.M. and Neary, J.P. (1982) 'Booming sector and de-industrialisation in a small open economy', The economic journal, 92 (368), pp. 825-848.

Davis, G.A. (1995) 'Learning to love the Dutch disease: Evidence from the mineral economies', World Development, 23 (10), pp. 1765-1779.

Dickey, D.A. and Fuller, W.A. (1979) 'Distribution of the estimators for autoregressive time series with a unit root', Journal of the American statistical association, 74 (366), pp. 427-431.

Dickey, D.A., Hasza, D.P. and Fuller, W.A. (1984) 'Testing for unit roots in seasonal time series', Journal of the American Statistical Association, 79 (386), pp. 355-367.

Dolado, J.J., Jenkinson, T. and Sosvilla-Rivero, S. (1990) 'Cointegration and unit roots', Journal of economic surveys, 4 (3), pp. 249-273.

Elliott, G., Rothenberg, T. J. and Stock, J. H., (1996) 'Efficient Tests for an Autoregressive Unit Root', 
Econometrica, 64(4), pp.813-836.

Emery, J.H., Ferrer, A. and Green, D. (2012) 'Long-term consequences of natural resource booms for human capital accumulation', ILR Review, 65 (3), pp. 708-734.

Enders, W. (2004) Applied econometric time series. 2nd edn. US: John Wiley \& Sons.

Engle, R. and Granger, C. (1987) 'Co-Integration and Error Correction: Representation, Estimation, and Testing', Econometrica, 55 (2), pp. 251-276.

Freedom House (2016) Countries at Crossroads. Available at: https://freedomhouse.org/report-types/countriescrossroads (Accessed 22 Jan 2017).

Gallego, F. (2010) 'Historical origins of schooling: the role democracy and political decentralization', Review of Economics and Statistics, 92 (2), pp. 228-243.

Galor, O. and Weil, D.N. (2000) 'Population, technology, and growth: From Malthusian stagnation to the demographic transition and beyond', American economic review, 90 (4), pp. 806-828.

Gelb, A.H. (1988) Oil windfalls: Blessing or curse?. United States: Oxford University Press.

Gupta, S., Verhoeven, M. and Tiongson, E.R. (2002) 'The effectiveness of government spending on education and healthcare in developing and transition economies', European Journal of Political Economy, 18(4), pp. 717 737.

Gylfason, T. (2001) 'Natural resources, education, and economic development', European Economic Review, 45 (4-6), pp. 847-859.

Hall, A. (1994) 'Testing for a unit root in time series with pretest data-based model selection', Journal of Business and Economic Statistics, 12 (4), pp. 461-470.

Hanushek, E.A. and Wößmann, L. (2007) The role of education quality for economic growth, World Bank Group, Working Papers No. 4122. World Bank, Washington, DC.

Hodler, R. (2006) 'The curse of natural resources in fractionalized countries', European Economic Review, 50 (6), pp. 1367-1386.

Johansen, S. and Juselius, K. (1990) 'Maximum likelihood estimation and inference on cointegration with application to the demand of money', Oxford Bulletin of Economics and Statistics, 52 (2), pp. 169-210.

Johansen, S. (1988) 'Statistical analysis of cointegration vectors', Journal of Economic Dynamics and Control, 12(2-3), pp. 231-254.

Johansen, S. (1992) 'Determination of cointegration rank in the presence of a linear trend', Oxford Bulletin of Economics and Statistics, 54 (3), pp. 383-397.

Johansen, S. (1995) Likelihood-based inference in cointegrated vector autoregressive models. United States Oxford: University Press.

Johansen, S., Mosconi, R. and Nielsen, B. (2000) 'Cointegration analysis in the presence of structural breaks in the deterministic trend', Econometrics Journal, 3(2), pp. 216-249.

Juselius, K. (2006) The cointegrated VAR model: methodology and applications, New York: Oxford University Press.

Krugman, P. (1987) 'The narrow moving band, the Dutch disease, and the competitive consequences of Mrs. Thatcher: Notes on trade in the presence of dynamic scale economies', Journal of Development Economics, 27 (1-2), pp. 41-55.

Kumar, A. (2017) 'Impact of Oil Boom and Bust on Human Capital Investment in the USA', Empirical Economics, 52(3), pp. 1089-1114.

Lane, P.R. and Tornell, A. (1996) 'Power, growth, and the voracity effect', Journal of economic growth, 1(2), pp. 213-241.

Lucas, R.E. (1988) 'On the mechanics of economic development', Journal of Monetary Economics, 22 (1) pp. 342.

Lütkepohl, H. and Krätzig, M. (eds.) (2004) Applied time series econometrics, US: Cambridge university press.

Matsuyama, K. (1992) 'Agricultural productivity, comparative advantage, and economic growth', Journal of Economic Theory, 58 (2), pp. 317-334.

McKinsey \& Co. (2015) Saudi Arabia beyond oil: the investment and productivity transmission. Available at:

https://www.mckinsey.com/ /media/McKinsey/Featured\%20Insights/Employment\%20and\%20Growth/Moving \%20Saudi\%20Arabias\%20economy\%20beyond\%20oil/MGI\%20Saudi\%20Arabia_Full\%20report_Decemb er\%202015.ashx (Accessed: 8 December 2016).

Nelson, R.R. and Phelps, E.S. (1966) 'Investment in humans, technological diffusion, and economic growth', The American Economic Review, 56 (1-2), pp. 69-75.

$\mathrm{Ng}$, S. and Perron, P. (2001) 'Lag length selection and the construction of unit root tests with good size and power', Econometrica, 69 (6), pp. 1519-1554.

Phillips, P.C. and Perron, P. (1988) ‘Testing for a unit root in time series regression', Biometrika, 75 (2), pp. 335 346.

Romer, P. (1990) 'Endogenous technological change', Journal of Political Economy, 98 (5), pp. 71-102. 
Shao, S. and Yang, L. (2014) 'Natural resource dependence, human capital accumulation, and economic growth: A combined explanation for the resource curse and the resource blessing', Energy Policy, 74, pp. 632-642.

Sims, C.A. (1980) 'Macroeconomics and reality', Econometrica: Journal of the Econometric Society, 48 (1), pp. $1-48$.

Stijns, J. (2006) 'Natural resource abundance and human capital accumulation', World Development, 34 (6), pp. 1060-1083.

Toews, G. and Libman, A., (2013) 'Natural resource booms and human capital investment', Oxford Center for the Analysis of Resource Rich Economies. (First draft).

Torvik, R. (2002) 'Natural resources, rent seeking and welfare', Journal of Development Economics, 67 (2), pp. 455-470.

World Bank (2017) Available at: www.worldbank.org/ (Accessed 22 November 2017).

World Bank (2002) Constructing knowledge societies: New challenges for tertiary education. Available at: http://siteresources.worldbank.org/TERTIARYEDUCATION/Resources/Documents/Constructing-KnowledgeSocieties/ConstructingKnowledgeSocieties.pdf (Accessed 22 August 2016).

\section{Acknowledgments}

Great thanks for Professor Kaddour Hadri and Dr. Renee Prendergast from Queen's University Management School, Belfast for their valuable comments and suggestions that contribute significantly to shape this paper. 